\title{
Electrical and Optical Simulation of Hybrid Perovskite-Based Solar Cell at Various Electron Transport Materials and Light Intensity
}

\author{
Abdel-Baset H. Mekky \\ Physics Department, Faculty of Science and Arts Al-methnab, Qassim University, El-Mithnab 51931, Saudi Arabia
}

Corresponding Author Email: A.Mekky@qu.edu.sa

https://doi.org/10.18280/acsm.440304

Received: 26 February 2020

Accepted: 19 March 2020

\section{Keywords:}

perovskite, electron transport layer, light intensity, GPVDM model, solar cells, performance parameters

\begin{abstract}
Perovskite-based solar cell knowledge has been a very attractive field of investigation in late years. It is a smart and appropriate material for the production of low prices, great efficiency, and sustainable photovoltaic cell. Perovskite-based solar cell modeling was performed in this study. Electrical and Optical Simulation of Hybrid Perovskite Solar Cell $\mathrm{CH}_{3} \mathrm{NH}_{3} \mathrm{PbI}_{3}$ was considered at different electron transport material ETM layers and light intensity by using the GPVDM Model at room temperature. To understand the effect of ETM layers on the performance of perovskite solar cells, various electron transport materials, including $\left(\mathrm{ETMs}=\mathrm{PCBM}, \mathrm{SiO}_{2}, \mathrm{ZnO}, \mathrm{TiO}_{2}, \mathrm{ZnSe}\right)$. The role of light intensity has been considered on the solar cell parameters (short-circuit photocurrent density, open-circuit voltage, fill factor, percent conversion efficiency, and maximum power). Also, the comparison between the special effects of regular and inverted structure device of architecture is examined. The results will contribute imperative standards and achievable directions for the production of higher efficiency Perovskite-based solar cells.
\end{abstract}

\section{INTRODUCTION}

Metal-halide perovskite solar cells have in recent times materialized at the front of such photovoltaic investigation and in a very short period time of around 5 years [1-8]. The examination in laboratories on hybrid organic and inorganic perovskites has come to be very concentrated. This innovative technology of perovskite solar cells has got a rapid development and for each time an innovative percentage of PCE power conversion efficiency that performs [9]. Currently, many investigators worldwide are employed on the improvement of photovoltaic devices that are favorable in producing clean energy in the future. The electrontransporting material layer (ETML), one of the greatest important modules in the PSCs Perovskites for extremely efficient performance, shows an important starring role in extracting and moving photogenerated electrons. At the same time, it also works as a hole blocking layer in order to suppress carrier recombination. The features of the ETML, especially its trap states, energy band, carrier mobility, and connected interfacial characteristics are major factors to examine the photovoltaic performance and device behavior of PSCs [10]. A rather great electron mobility is desirable for ETMLs to capably transport and gather electrons transport, causal to the arising value of (Jsc) short-circuit current density, and also (FF) fill factor. The good equivalent energy level between ETLs and the perovskite layer can enable electron transport and extraction. Moreover, the (Voc) open-circuit voltage can be defined by the energy level differences between the Fermi levels of the EF and ETL of the (HTL) hole-transporting layer [11-13]. Therefore, the energy level is commonly used to develop the Voc of a solar cell device. Trap states of the ETMLs also play significant roles in charge transport. Consequently, increasing interface contact between the perovskite layer and ETMLs is an effective method to enhance solar cell performance and improve charge transport. Up to the present time, $\mathrm{TiO}_{2}$ has been used as ETML in most regularly reported PSCs. The electron injection amounts between the $\mathrm{TiO}_{2}$ as ETL and perovskite absorber are very rapid, but the great electron recombination amounts are also found due to the small transport properties and electron mobility [14]. Also, a high-temperature procedure was necessary for a good mesoscopic $\mathrm{TiO}_{2}$ layer [15]. Therefore, these properties of $\mathrm{TiO}_{2}$ may act as disablements to improve solar cell performance and the additional application for improving low price perovskite solar cells $[16,17]$. Oppositely, $\mathrm{ZnO}$ is an extensive bandgap semiconductor of the second and sixth semiconductor group that has many favorable characteristics involving good transparency, large bandgap, and great luminescence at room temperature. By using the small temperature solution methods many types of morphologies in $\mathrm{ZnO}$ have been made. The intrinsic doping of the semiconductor because of zinc interstitials or oxygen vacancies is n-type [18]. Furthermore, $\mathrm{ZnO}$ is a well-known oxide metal that has an alike energy level such as $\mathrm{TiO}_{2}$, on the other hand, has high electron mobility than $\mathrm{TiO}_{2}[19,20]$, that lets it a perfect candidate for a low-temperature method for processed electron selective interaction for transparent electrodes, light-emitting diodes, and organic solar cell thin film. The modeling and simulation software establishes an interesting tool to realize high photovoltaic solar cell efficiency [21, 22]. Over the years, the numerical simulation technique of solar cell devices has proven to be a feasible tool for understanding and examining the characteristics of the solar cell as the electrical, optical and mechanical properties of multilayers solar cells [23]. It also provides to reduce the costs and time spent for the fabrication of solar cell devices by given that valuable information in what way to vary the solar 
cell parameters to enhance the solar cell performance [24]. Many parameters can improve the (PCE) percent conversion efficiency in perovskite-based solar cells; one of them is the nature and kind of electron-transporting material layer (ETML). In the present paper, we used GPVDM which is a powerful simulator for solar cells, where the effect of different ETMs layer on power conversion efficiency and other parameters of a planar heterojunction solar cell using $\mathrm{CH}_{3} \mathrm{NH}_{3} \mathrm{PbI}_{3}$ as an absorber layer, is investigated. The results of the solar cell output parameter variant in terms of light intensity and the comparison between the effects of regular and inverted structure device of architecture.

\section{DEVICE STRUCTURE}

A representative perovskite-based solar cells PSCs structure consists of $\left(\mathrm{CH}_{3} \mathrm{NH}_{3} \mathrm{PbI}_{3}\right)$ as an absorber layer which is the main carrier generator, at the top p-type (HTM = PEDOT: PSS) and n-type (ETMs $=$ PCBM, $\left.\mathrm{SiO}_{2}, \mathrm{ZnO}, \mathrm{TiO}_{2}, \mathrm{ZnSe}\right)$ is arranged at the bottom side. The hole collector electrode material is FTO (fluorine tin oxide) glass. The perovskite absorber material is deposited on FTO glass. As observed, the device has a multilayer structure that consists of FTO/PEDOT: $\mathrm{PSS} / \mathrm{CH}_{3} \mathrm{NH}_{3} \mathrm{PbI}_{3} / \mathrm{ETMs} / \mathrm{Ag}$. The device structure of perovskite solar cells used in this work is shown in Figure 1 and Figure 2.

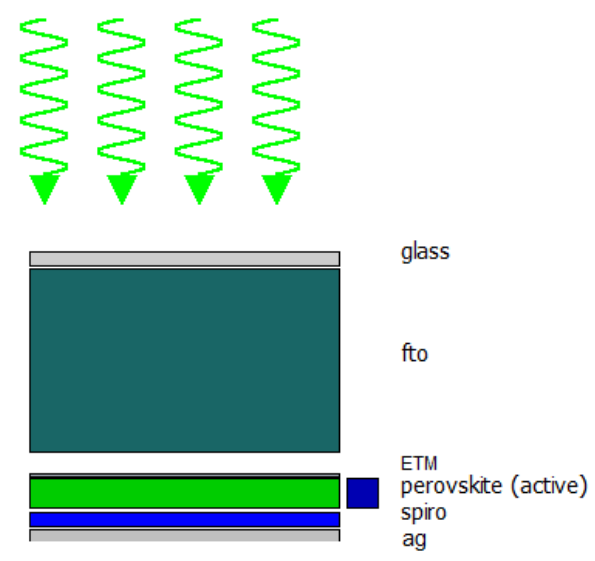

Figure 1. Schematic representation (regular) structure device of architecture (Glass/FTO/ETMs/ $\mathrm{CH}_{3} \mathrm{NH}_{3} \mathrm{PbI}_{3} / \mathrm{PEDOT:}$ PSS/Ag), (structure 1)

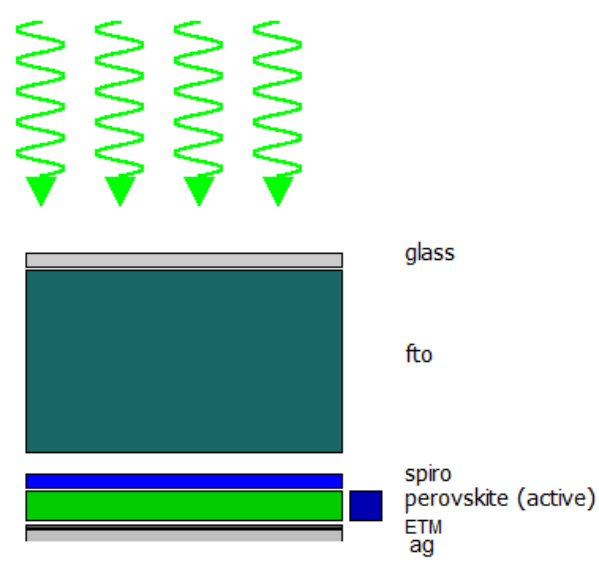

Figure 2. Schematic representation (inverted) structure device of architecture (Glass/FTO/ PEDOT: PSS

$/ \mathrm{CH}_{3} \mathrm{NH}_{3} \mathrm{PbI}_{3} / \mathrm{ETMs} / \mathrm{Ag}$ ), (structure 2)
Figure $3(a, b)$ is shown the parameters thickness, optical materials, and layer types used for the simulation for regular (structure 1) and inverted (structure 2) structure device of architecture cases, respectively.

\begin{tabular}{|l|l|l|}
\hline \multicolumn{1}{|c|}{ Layer name } & \multicolumn{1}{|c|}{ Thicknes } & \multicolumn{1}{c|}{ Optical material } \\
\hline glass & $100 \mathrm{e}-9$ & glasses/glass \\
\hline fto & $1.2 \mathrm{e}-06$ & oxides/fto \\
\hline ETM & $2.5 \mathrm{e}-08$ & refractiveindex.info/main/ \\
\hline perovskite & $2 \mathrm{e}-07$ & perovskites/std_preovskite \\
\hline spiro & $1 \mathrm{e}-07$ & small_molecules/spiromeotad \\
\hline ag & $2 \mathrm{e}-07$ & metal/ag
\end{tabular}

(a) Case of regular structure device of architecture, (structure 1)

\begin{tabular}{|lll|}
\hline \multicolumn{1}{|c|}{ Layer name } & \multicolumn{1}{c}{ Thicknes } & \multicolumn{1}{c|}{ Optical material } \\
\hline glass & $100 \mathrm{e}-9$ & glasses/glass \\
\hline fto & $1.2 \mathrm{e}-06$ & oxides/fto \\
\hline spiro & $1 \mathrm{e}-07$ & small_molecules/spiromeotad \\
\hline perovskite & $2 \mathrm{e}-07$ & perovskites/std_preovskite \\
\hline ETM & $2.5 \mathrm{e}-08$ & oxides/
\end{tabular}

(b) Case of inverted structure device of architecture, (structure 2)

Figure 3. Individual layer parameters set in GPVDM environment

\section{SIMULATION TECHNIQUE}

Electrical and optical simulation of solar cells has been done at different active layer thickness using GPVDM Software which is developed for the simulation of solar cells. Both optical \& electrical simulation can be done using this software under various types of electron-transporting material layer ETMs, and light intensities (G) ranging from 0.001 to 10 $\left(\mathrm{mW} . \mathrm{cm}^{-2}\right)$. At the room temperature, the fill factor (FF), short-circuit photocurrent density $\left(\mathrm{J}_{\mathrm{SC}}\right)$, percent conversion efficiency (PCE), open-circuit voltage $\left(\mathrm{V}_{\mathrm{OC}}\right)$, and maximum power (Pmax) were calculated by GPVDM software as performance parameters for PSCs. Materials used for the design and bandwidth values data of materials are given in Figures 1, 2 and $3(\mathrm{a}, \mathrm{b})$. Perovskite electrical and optical parameters are set from the GPVDM software database based on the reference [25]. To examine the proposed structure and its characteristics, the GPVDM simulator is used to explore the efficiency and primary parameter. We run the software for five types of electron-transporting material layer ETMs $\left(\mathrm{SiO}_{2}, \mathrm{ZnO}\right.$, $\mathrm{TiO}_{2}, \mathrm{PC}_{60} \mathrm{BM}$, and $\mathrm{ZnSe}$ ) to get the performance parameters of Perovskite at different ETMs. Simulation for each ETMs separately has been done for different light of intensities to get information like Fill factor, power conversion efficiency, open-circuit voltage, short circuit current density, and maximum power.

\section{RESULTS AND DISCUSSION}

Many metal oxides have been used to analyze the role of the 
electron transporting layer in the perovskite thin-film solar cells. Here simulation works are carried out all using some materials as ETMs with varying solar cell parameters. Effect of the type of electrons transporting layers (EsTLs) on short- circuit photocurrent density (Jsc), open-circuit voltage (Voc), fill factor (FF), percent conversion efficiency (PCE), and maximum power (Pmax) at $(\mathrm{G})$ light intensity $1\left(\mathrm{~mW} . \mathrm{cm}^{-2}\right)$ at room temperature, is given in Table 1.

Table 1. Performance parameters for PSCs prepared with different ETMs

\begin{tabular}{|c|c|c|c|c|c|}
\hline$\underbrace{\text { Parameter }}_{\text {ETMs }}$ & FF (\%) & $\operatorname{Voc}(V)$ & $\operatorname{Jsc}\left(\mathrm{A} / \mathrm{cm}^{-2}\right)$ & PCE (\%) & Max. power (watts) \\
\hline $\mathrm{SiO}_{2}$ & 0.74522 & 0.44731 & 223.5844 & 7.4532 & 74.532567 \\
\hline $\mathrm{ZnO}$ & 0.74504 & 0.44792 & 227.8618 & 7.6042 & 76.042666 \\
\hline $\mathrm{TiO}_{2}$ & 0.74444 & 0.44943 & 238.5488 & 7.9813 & 79.813747 \\
\hline $\mathrm{PC}_{60} \mathrm{BM}$ & 0.74475 & 0.44866 & 233.1109 & 7.7892 & 77.892982 \\
\hline ZnSe & 0.74491 & 0.44824 & 230.1129 & 7.6834 & 76.834720 \\
\hline
\end{tabular}

Table 2. Influence of light intensity $\left(\mathrm{mW} . \mathrm{cm}^{-2}\right)$ on (FF) of PSCs with different ETMs

\begin{tabular}{|c|c|c|c|c|c|}
\hline FF (\%) & 0.001 & 0.01 & 0.1 & 1 & 10 \\
\hline $\mathrm{SiO}_{2}$ & 0.320155 & 0.643277 & 0.729799 & 0.745228 & 0.725024 \\
\hline $\mathrm{ZnO}$ & 0.323428 & 0.645009 & 0.729819 & 0.745043 & 0.724614 \\
\hline $\mathrm{TiO}_{2}$ & 0.330632 & 0.648880 & 0.729663 & 0.744440 & 0.723406 \\
\hline $\mathrm{PC}_{60} \mathrm{BM}$ & 0.327131 & 0.646981 & 0.729766 & 0.744752 & 0.724034 \\
\hline ZnSe & 0.325056 & 0.645870 & 0.729798 & 0.744911 & 0.724360 \\
\hline
\end{tabular}

The FF is highest at the $\mathrm{SiO}_{2}$ layer as ETM. The percent conversion efficiency (PCE) of using $\mathrm{TiO}_{2}$ as ETM is much higher compared to other items of ETMs. The perovskite solar cell device based on the pure $\mathrm{TiO}_{2}$ interlayer showed an efficiency of $7.981375 \%$ with a Voc of $0.449439 \mathrm{~V}$, Jsc of $238.5488 \mathrm{~mA} \mathrm{~cm}^{-2}$, and FF of $0.744440 \%$. We used different materials as the electronic transport layer, and all of them exhibited various degrees of enhancement on device performances. That one of $\mathrm{TiO}_{2}$ is resulting in a higher PCE, which is better than the other devices. Jsc has a directly proportional with various ETMs at the conditions of light intensity.

For different ETMs layers the effect of light intensity on short-circuits photocurrent density (Jsc), open-circuit voltage (Voc), fill factor (FF), percent conversion efficiency (PCE), and maximum power (Pmax) all with $(G)$ light intensities $0.001,0.01,0.1,1$ and $10\left(\mathrm{~mW} . \mathrm{cm}^{-2}\right)$ at room temperature is simulated. The fill factor (FF) is mainly affected by light intensity (Figure 4 and Table 2). FF of the device increases up to when the light intensity reaches $1 \mathrm{~mW} / \mathrm{cm}^{2}$. When the light intensity reaches $10 \mathrm{~mW} / \mathrm{cm}^{2}$, then $\mathrm{FF}$ drops due to the influence of series resistance [26].

The open-circuit voltage (Voc) is related to light intensity. On this basis, we have established a simulation for the relationship between the open-circuit voltage and the light intensity. Figure 5 and Table 3 show the open-circuit voltage versus light intensity for devices of various ETMs. An increased charge generation rate results in an increased chemical potential within the device and thus an increase in the open-circuit voltage. However, the reduced charge lifetime reduces the chemical potential within the device and acts as to reduce the open-circuit voltage. The observed behavior is due to the charge generation rate increasing more strongly with intensity than the reduction of the charge lifetime. So, the open-circuit voltage increases with light intensity.

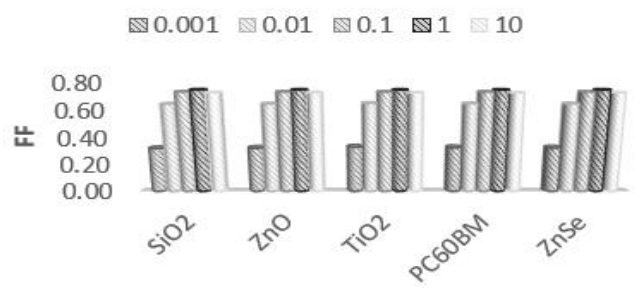

Figure 4. Influence of light intensity $\left(\mathrm{mW} \cdot \mathrm{cm}^{-2}\right)$ on (FF) of PSCs with different ETMs

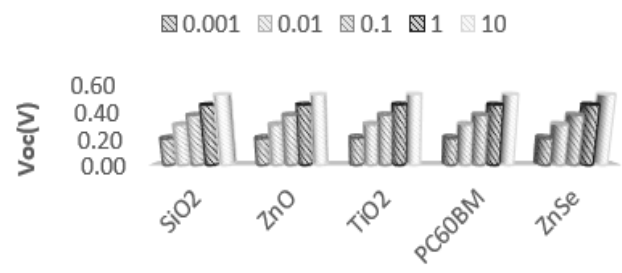

Figure 5. Influence of light intensity $\left(\mathrm{mW} . \mathrm{cm}^{-2}\right)$ on opencircuit voltage (Voc) of PSCs with different ETMs

Table 3. Influence of light intensity $\left(\mathrm{mW} . \mathrm{cm}^{-2}\right)$ on open-circuit voltage (Voc) of PSCs with different ETMs

\begin{tabular}{|c|c|c|c|c|c|}
\hline $\operatorname{Voc}(V)$ & 0.001 & 0.01 & 0.1 & 1 & 10 \\
\hline $\mathrm{SiO}_{2}$ & 0.200112 & 0.302869 & 0.373094 & 0.447317 & 0.522609 \\
\hline $\mathrm{ZnO}$ & 0.201329 & 0.303356 & 0.373760 & 0.447924 & 0.523085 \\
\hline $\mathrm{TiO}_{2}$ & 0.204368 & 0.304573 & 0.375423 & 0.449439 & 0.524270 \\
\hline $\mathrm{PC}_{60} \mathrm{BM}$ & 0.202821 & 0.303953 & 0.374575 & 0.448667 & 0.523666 \\
\hline ZnSe & 0.201968 & 0.303612 & 0.374109 & 0.448242 & 0.523333 \\
\hline
\end{tabular}


Table 4. Influence of light intensity ranging from 0.001 to $10 \mathrm{~mW} / \mathrm{cm}^{2}$ on Jsc of PSCs

\begin{tabular}{cccccc}
\hline $\mathbf{J s c}\left(\mathbf{A} / \mathbf{c m}^{-2}\right)$ & $\mathbf{0 . 0 0 1}$ & $\mathbf{0 . 0 1}$ & $\mathbf{0 . 1}$ & $\mathbf{1}$ & $\mathbf{1 0}$ \\
\hline $\mathbf{S i O}_{\mathbf{2}}$ & 0.2235830 & 2.23583 & 22.35837 & 223.5844 & 2235.656 \\
$\mathbf{Z n O}$ & 0.2278604 & 2.27860 & 22.78611 & 227.8618 & 2278.424 \\
$\mathbf{T i O}_{\mathbf{2}}$ & 0.2385473 & 2.38547 & 23.85481 & 238.5488 & 2385.279 \\
$\mathbf{P C}_{\mathbf{6 0}} \mathbf{B M}$ & 0.2331094 & 2.33109 & 23.31101 & 233.1109 & 2330.909 \\
$\mathbf{Z n S e}$ & 0.2301113 & 2.3011 & 23.01120 & 230.1129 & 2300.933 \\
\hline
\end{tabular}

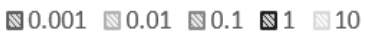

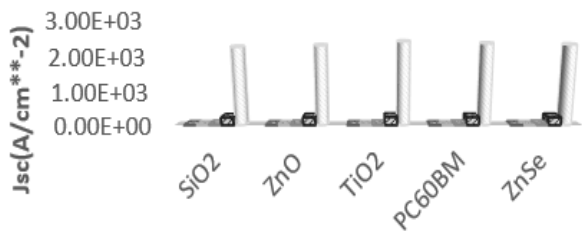

Figure 6. Influence of light intensity ranging from 0.001 to $10 \mathrm{~mW} / \mathrm{cm}^{2}$ on Jsc of PSCs

The light generated current is proportional to the flux of photons therefore Jsc is directly proportional to the light intensity $[27,28]$. The Jsc was calculated as a function of the light intensity for various ETMs of device to investigate the main effect of them in the PSCs. In the plot of Figure 6, and Table 4, the Jsc as a directly proportional function of light intensity for various ETMs. On the other hand, there is a linear boost in the Jsc in line with the minority carrier concentration, due to the increase in light intensity. Surface plots of Jsc indicate a linear response with respect to illumination intensity. Also, it can well explain the improvement of the short-circuit current density for the using $\mathrm{TiO}_{2}$ layer device compared with the other types of ETMs for device.

To examine if the change in light intensity could explain the increase in percent conversion efficiency PCE, a curve was simulated with the model using different light intensity and the PCE resulting device efficiency plotted. The results are shown in Figure 7 and Table 5, with the light intensity increase from 0.001 to $10 \mathrm{~mW} / \mathrm{cm}^{2}$, PCE increases ranging. This is due to the charge/discharge current into the capacitive element in the devices not by real photo-generated one.

The increase in percent conversion efficiency PCE is caused by optical absorption in the absorber layer and hence efficient charge separation at the perovskite interface $9.046417 \%$ when the irradiation varies from 0.001 to $10 \mathrm{~mW} / \mathrm{cm}^{2}$.

The maximum power (Pmax) produced by a solar cell is reached when the product $\mathrm{I}-\mathrm{V}$ is maximum. In Figure 8 and Table 6 , the maximum power of the studied solar cell in terms of light intensity is shown. However, shows that the maximum power increases with increasing the light intensity. Such an increase in the maximum power is primarily caused by a rise in the Voc and also by the corresponding linear increase in the photocurrent with the light intensity.

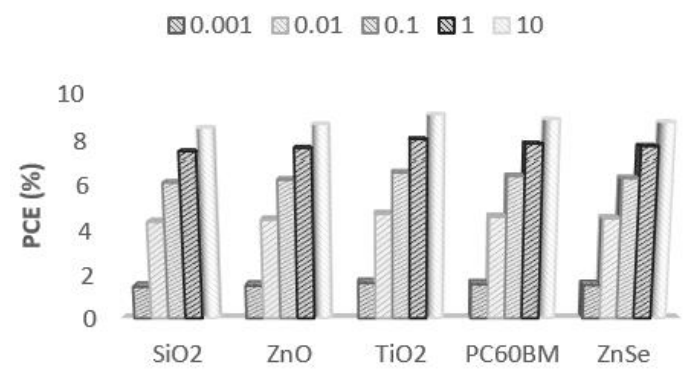

Figure 7. Influence of light intensity ranging from 0.001 to $10 \mathrm{~mW} / \mathrm{cm}^{2}$ on PCE of PSCs

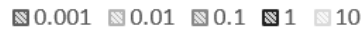

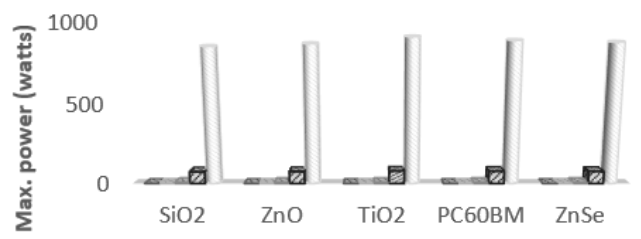

Figure 8. Influence of light intensity ranging from 0.001 to $10 \mathrm{~mW} / \mathrm{cm}^{2}$ on Pmax of PSCs

In our work, we have shown how this solar cell can exhibit high percent conversion efficiency (PCE) at the interface of the $\mathrm{CH}_{3} \mathrm{NH}_{3} \mathrm{PbI}_{3}$ in contact with $\mathrm{TiO}_{2}$. So that, Solar cell performance parameters extracted from the reverse current at ETM $\left(\mathrm{TiO}_{2}\right)$ with light intensity $1 \mathrm{~mW} / \mathrm{cm}^{2}$ as the case of study in Table 7. The performing regular structure device gives a PCE of $7.981375 \%\left(\mathrm{~J}_{\mathrm{sc}}\right.$ of $2.385488 \mathrm{e}+2 \mathrm{~mA} \mathrm{~cm}{ }^{-2}, \mathrm{~V}_{\mathrm{oc}}$ of $0.449439 \mathrm{~V}$, and FF of 0.744440$)$. The inverted devices instead give a PCE of $7.467964 \%\left(\mathrm{~J}_{\mathrm{sc}}\right.$ of $2.239918 \mathrm{e}+2 \mathrm{~mA}$ $\mathrm{cm}^{-2}, \mathrm{~V}_{\mathrm{oc}}$ of $0.447376 \mathrm{~V}, \mathrm{FF}$ of 0.745242$)$. The solar cells based on the regular device architecture (structure 1) are much better in performance than those based on the inverted device architecture (structure 2).

Table 5. Influence of light intensity ranging from 0.001 to $10 \mathrm{~mW} / \mathrm{cm}^{2}$ on PCE of PSCs

\begin{tabular}{cccccc}
\hline PCE (\%) & $\mathbf{0 . 0 0 1}$ & $\mathbf{0 . 0 1}$ & $\mathbf{0 . 1}$ & $\mathbf{1}$ \\
\hline $\mathbf{S i O}_{2}$ & 1.432428 & 4.356048 & 6.087816 & 7.453257 \\
$\mathbf{Z n O}$ & 1.483722 & 4.458491 & 6.215527 & 7.604267 \\
$\mathbf{T i O}_{2}$ & 1.611878 & 4.714444 & 6.534593 & 7.981375 \\
PC60M & 1.546658 & 4.584150 & 6.372125 & 7.636009 & 9.046417 \\
$\mathbf{Z n S e}$ & 1.510705 & 4.512343 & 6.282606 & 8.837687 & 7.683472 \\
\hline
\end{tabular}


Table 6. Influence of light intensity ranging from 0.001 to $10 \mathrm{~mW} / \mathrm{cm}^{2}$ on Pmax of PSCs

\begin{tabular}{cccccc}
\hline Max. power (watts) & $\mathbf{0 . 0 0 1}$ & $\mathbf{0 . 0 1}$ & $\mathbf{0 . 1}$ & $\mathbf{1}$ & $\mathbf{1 0}$ \\
\hline $\mathbf{S i O}_{2}$ & 0.014324 & 0.435605 & 6.087816 & 74.532567 & 847.09944 \\
$\mathbf{Z n O}$ & 0.014837 & 0.445849 & 6.215527 & 76.042666 & 863.60085 \\
$\mathbf{T i O}_{2}$ & 0.016119 & 0.471444 & 6.534593 & 79.813747 & 904.64170 \\
$\mathbf{P C}_{\mathbf{6 0}} \mathbf{B M}$ & 0.015467 & 0.458415 & 6.372125 & 77.892982 & 883.76871 \\
$\mathbf{Z n S e}$ & 0.015107 & 0.451234 & 6.282606 & 76.834720 & 872.24110 \\
\hline
\end{tabular}

Table 7. Performance parameters for perovskite thin-film solar cells prepared with different regular and inverted structure device of architecture

\begin{tabular}{|c|c|c|c|c|c|}
\hline $\mathrm{G}=1\left(\mathrm{~mW} / \mathrm{cm}^{2}\right)$ & FF (\%) & $\operatorname{Voc}(\mathrm{V})$ & $\mathrm{Jsc}\left(\mathrm{mA} / \mathrm{cm}^{-2}\right)$ & PCE (\%) & $\operatorname{Pmax}(w)$ \\
\hline $\mathrm{TiO}_{2}$ (structure 1) & 0.744440 & 0.449439 & 238.5488 & 7.981375 & 79.81374 \\
\hline $\mathrm{TiO}_{2}$ (structure 2) & 0.745242 & 0.447376 & 223.9918 & 7.467964 & 74.67963 \\
\hline
\end{tabular}

\section{CONCLUSIONS}

The influence of electron transport material layers (ETMLs) and the light intensity effect on the performance of perovskite solar cells are analyzed by using GPVDM software. The shortcircuit photocurrent density, open-circuit voltage, fill factor, power conversion efficiency, and maximum power, of perovskite solar cells, vary with the intensity of light. The light intensity variation ranging from 0.001 to $10\left(\mathrm{~mW} . \mathrm{cm}^{-2}\right)$. Variation of the light intensity incident on a solar cell changes all solar cell parameters. The variation in light intensity significantly affects the Jsc. Changes in the illumination intensity between $10^{-2}$ to $10^{2} \mathrm{~mW} \cdot \mathrm{cm}^{-2}$ causes a proportional change in the Jsc for all solar cells. The trend observed in JSc is directly proportional to the number of photons absorbed by the semiconducting material. Surface plots of Jsc indicate a linear response with respect to illumination intensity. From this simulation, we have seen that the PCE of this solar cell is strongly dependent on the light intensity conditions and shows a dramatically decrease of the efficiencies with decreasing light intensity. Voc depends on light intensity. FF monotonically increased up to the intensity of $10 \mathrm{~mW} \cdot \mathrm{cm}^{-2}$. From the results obtained, it can be concluded that the best way to improve the performance of the solar system is by maximizing the light intensity falling on the solar cell's surface to enhance the maximum output power of the solar system. The solar cells based on the regular device architecture are much better in performance than those based on the inverted device architecture. The above results will give imperative baselines and feasible directions for the fabrication of higher efficiency perovskite solar cells.

\section{REFERENCES}

[1] Kojima, A., Teshima, K., Shirai, Y., Miyasaka, T. (2009). Organometal halide perovskites as visible - light sensitizers for photovoltaic cells. J Am Chem Soc., 131(17): 6050-6051. https://doi.org/10.1021/ja809598r

[2] Burschka, J., Pellet, N., Moon, S.J., Humphry-Baker, R., Gao, P., Nazeeruddin, M.K., Grätzel, M. (2013). Sequential deposition as a route to high-performance perovskite-sensitized solar cells. Nature, 499(7458): 316-319. https://doi.org/10.1038/nature12340

[3] Jeon, N.J., Noh, J.H., Kim, Y.C., Yang, W.S., Ryu, S., Seok, S.I. (2014). Solvent engineering for highperformance inorganic-organic hybrid perovskite solar cells. Nature Materials, 13(9): 897-903.

\section{https://doi.org/10.1038/nmat4014}

[4] Lee, M.M., Teuscher, J., Miyasaka, T., Murakami, T.N., Snaith, H.J. (2012). Efficient hybrid solar cells based on meso-superstructured organometal halide perovskites. Science, $\quad$ 80(338): https://doi.org/10.1126/science.1228604

[5] Stranks, S.D., Eperon, G.E., Grancini, G., Menelaou, C., Alcocer, M.J.P., Leijtens, T., Herz, L.M., Petrozza, A., Snaith, H.J. (2013). Electron-hole diffusion lengths exceeding 1 micrometer in an organometal trihalide perovskite absorber. Science, 342(6156): 341-344. https://doi.org/10.1126/science. 1243982

[6] Wang, Y., Xia, Z., Liu, Y., Zhou, H. (2015). Simulation of perovskite solar cells with inorganic hole transporting materials. 2015 IEEE 42nd Photovolt Spec Conf PVSC, New Orleans, LA, USA, pp. 3-6. https://doi.org/10.1109/PVSC.2015.7355717

[7] Xiao, M., Huang, F., Huang, W., Dkhissi, Y., Zhu, Y., Etheridge, J., Gray-Weale, A., Bach, U., Cheng, Y.B., Spiccia, L. (2014). A fast deposition-crystallization procedure for highly efficient lead iodide perovskite thinfilm solar cells. Angewandte Chemie International Edition, 53(37): 9898-903. https://doi.org/10.1002/anie.201405334

[8] Yang, W.S., Noh, J.H., Jeon, N.J., Kim, Y.C., Ryu, S., Seo, J., Seok, S.I. (2015). High-performance photovoltaic perovskite layers fabricated through intramolecular exchange. Sci., 348(6240): 1234-7. https://doi.org/10.1126/science.aaa9272

[9] Hima, A., Khechekhouche, A., Kemerchou, I., Lakhdar, N., Benhaoua, B., Rogti, F., Telli, I., Saadoun, A. (2018). GPVDM simulation of layer thickness effect on power conversion efficiency of $\mathrm{CH}_{3} \mathrm{NH}_{3} \mathrm{PbI}_{3}$ based planar heterojunction solar cell. Materials Science, 3(1): 37-41.

[10] Yang, G., Tao, H., Qin, P., Ke, W., Fang, G. (2016). Recent progress in electron transport layers for efficient perovskite solar cells. Journal of Materials Chemistry A, 4(11): 3970-3990. https://doi.org/10.1039/c5ta09011c

[11] Chiang, Y.F., Jeng, J.Y., Lee, M.H., Peng, S.R., Chen, P., Guo, T.F., Wen, T.C., Hsu, Y.J., Hsu, C.M. (2014). High voltage and efficient bilayer heterojunction solar cells based on an organic-inorganic hybrid perovskite absorber with a low-cost flexible substrate. Physical Chemistry Chemical Physics, 16(13): 6033-6040. https://doi.org/10.1039/c4cp00298a

[12] Ryu, S., Noh, J.H., Jeon, N.J., Chan Kim, Y., Yang, W.S., Seo, J., Seok, S.I. (2014). Voltage output of efficient perovskite solar cells with high open-circuit voltage and 
fill factor. Energy \& Environmental Science, 7(8): 26148. https://doi.org/10.1039/c4ee00762j

[13] Yusoff, A.R.B.M., Nazeeruddin, M.K. (2016). Organohalide lead perovskites for photovoltaic applications. J. Phys. Chem. Lett., 7(5): 851-66. https://doi.org/10.1021/acs.jpclett.5b02893

[14] Gubbala, S., Chakrapani, V., Kumar, V., Sunkara, M.K. (2008). Band-edge engineered hybrid structures for dyesensitized solar cells based on $\mathrm{SnO}_{2}$ nanowires. Advanced Functional Materials, 18(16): 2411-2418. https://doi.org/10.1002/adfm.200800099

[15] Jeon, N.J., Noh, J.H., Yang, W.S., Kim, Y.C., Ryu, S., Seo, J., Seok, S.I. (2015). Compositional engineering of perovskite materials for high-performance solar cells. Nature, 517: 476-480. https://doi.org/10.1038/nature14133

[16] Beiley, Z., McGehee, M.D. (2012). Modeling low-cost hybrid tandem photovoltaics with power conversion efficiencies exceeding 20\%. Energy \& Environmental Science, 11: 3129-3130. https://doi.org/10.1109/PVSC.2012.6318242

[17] Roldán-Carmona, C., Malinkiewicz, O., Soriano, A., Mínguez Espallargas, G., Garcia, A., Reinecke, P., Kroyer, T., Dar, M.I., Nazeeruddin, M.K., Bolink, H.J. (2014). Flexible high efficiency perovskite solar cells. Energy \& Environmental Science, 7(3): 994-997. https://doi.org/10.1039/c3ee43619e

[18] Özgür, Ü., Alivov, Y.I., Liu, C., Teke, A., Reshchikov, M.A., Doğan, S., Avrutin, V., Cho, S.J., Morko, H. (2005). A comprehensive review of $\mathrm{ZnO}$ materials and devices. Journal of Applied Physics, 98(4): 1-103. https://doi.org/10.1063/1.1992666

[19] Bae, H.S., Yoon, M.H., Kim, J.H., Im, S. (2003). Photodetecting properties of $\mathrm{ZnO}$-based thin-film transistors. Applied Physics Letters, 83(25): 5313-5315. https://doi.org/10.1063/1.1633676

[20] Tang, H., Prasad, K., Sanjinès, R., Schmid, P.E., Lévy, F. (1994). Electrical and optical properties of $\mathrm{TiO}_{2}$ anatase thin films. Journal of Applied Physics, 75(4): 2042-2047. https://doi.org/10.1063/1.356306

[21] Mekky, A.B.H. (2019). Simulation and modeling of the influence of temperature on $\mathrm{CdS} / \mathrm{CdTe}$ thin film solar cell. Eur. Phys. J. Appl. Phys., 87(3): 30101. https://doi.org/10.1051/epjap/2019190037

[22] Assal, S., Yadir, S., Amiry, H., Sidki, M., Benhmida, M. (2014). Analysis of technological factors's influence on solar cell's performance by PC1D simulation. 2014 International Renewable and Sustainable Energy Conference (IRSEC), Ouarzazate, Morocco, pp. 1-5. https://doi.org/10.1109/IRSEC.2014.7059806

[23] Burgelman, M., Verschraegen, J., Degrave, S., Nollet, P. (2004). Modeling thin-film PV devices. Progress in Photovoltaics: Research and Applications, 12(2-3): 14353. https://doi.org/10.1002/pip.524

[24] Minemoto, T., Murata, M. (2014). Device modeling of perovskite solar cells based on structural similarity with thin film inorganic semiconductor solar cells. Journal of Applied $\quad$ Physics, 116(5): 054505. https://doi.org/10.1063/1.4891982

[25] Mackenzie, R.C.I. (2016). Gpvdm manual. 1-26. https:/www.opvdm.com/docs/gpvdm_documentation.p df, accessed on Feb. 18, 2020.

[26] Chegaar, M., Hamzaoui, A., Namoda, A., Petit, P., Aillerie, M., Herguth, A. (2013). Effect of illumination intensity on solar cells parameters. Energy Procedia, 36: 722-729. https://doi.org/10.1016/j.egypro.2013.07.084

[27] Cuce, E., Cuce, P.M., Bali, T. (2013). An experimental analysis of illumination intensity and temperature dependency of photovoltaic cell parameters. Applied Energy, 111: 374-382. https://doi.org/10.1016/j.apenergy.2013.05.025

[28] Yadav, A.K., Chandel, S.S. (2013). Tilt angle optimization to maximize incident solar radiation: A review. Renewable and Sustainable Energy Reviews, 23: 503-513. https://doi.org/10.1016/j.rser.2013.02.027 